\title{
ANALISIS KOMPONEN TINGKAT KESEHATAN BANK TERHADAP HARGA SAHAM BANK UMUM SWASTA NASIONAL DEVISA YANG TERDAFTAR DI BURSA EFEK INDONESIA PERIODE 2012-2016
}

\author{
Hana Medyawicesar \\ Universitas Pendidikan Indonesia \\ Hana.medyawicesar@student.upi.edu \\ Eded Tarmedi \\ Universitas Pendidikan Indonesia \\ Ededtarmedi@upi.edu \\ Imas Purnamasari \\ Universitas Pendidikan Indonesia \\ Imaspurnamasari@upi.edu
}

\begin{abstract}
ABSTRAK
Tujuan - Tujuan dari penelitian ini adalah untuk menganalisis tingkat kesehatan bank dengan menggunakan metode RGEC dan pengaruhnya terhadap harga saham

Desain / metodologi / pendekatan - Metode yang digunakan dalam penelitian ini adalah metode deskriptif dan verifikatif. Data yang digunakan adalah data sekunder dari masing-masing Bank Umum Swasta Nasional Devisa yang terdaftar di BEI dengan teknik analisis menggunakan regresi linier multipel. Sampling dalam penelitian ini menggunakan purposive sampling.

Temuan - Hasil penelitian menunjukkan NPL dan ROA berpengaruh positif terhadap harga saham, GCG dan NIM tidak berpengaruh terhadap harga saham, LDR dan CAR tidak berpengaruh terhadap harga saham tetapi arah regresi bertanda positif menunjukan hubungan yang searah dengan harga saham.

Orisinalitas - Perbedaan penelitian dengan penelitian sebelumnya adalah pada objek dan metode penelitian, populasi dan sampel penelitian, periode penelitian, alat ukur dan hasil penelitian, serta sumber teori dan jurnal asing dan buku asing serta hasil penelitian.
\end{abstract}

Kata kunci: Tingkat kesehatan bank, RGEC, harga saham, bank umum swasta nasional devisa Pasal Jenis: Penelitian Studi Kasus

\section{ABSTRACT}

Purpose - The purpose of this study was to analyze the description of Bank Soundness by using RGEC method and influence on stock price

Design / methodology / approach - Method in this research used descriptive and verification methods. Data that used are secondary data of each Public bank foreign exchange on Indonesia Stock Exchange with analysis technique using multiple linear regression. Sampling in this research use purposive sampling

Findings - The result of this research shows that NPL and ROA have positive effect to share price, GCG and NIM have no effect to stock price, LDR and CAR do not have an effect on stock price but regression direction with positive sign showing relationship with stock price.

Originality -The difference of this research with previous research is on research object and method, population and research sample, research period, measuring instrument and research result, as well as foreign theory and journal source and foreign book and research result.

Keywords : Bank Soundness, RGEC, Stock Price, Public bank foreign exchange

Article Type: Case Study paper

\section{PENDAHULUAN}

Pasar modal merupakan lembaga yang memobilisasi dana masyarakat dengan menyediakan fasilitas atau tempat mempertemukan dua pihak yang memerlukan dana (emiten) dan pihak yang kelebihan dana (investor) (Hakmi, Rahayu, Administrasi, \& Brawijaya, 2017). Lembaga penunjang untuk mempertemukan dua pihak tersebut yaitu Bursa
Efek Indonesia (BEI). Perkembangan bursa efek dapat dilihat dengan semakin banyaknya anggota bursa atau juga dapat dilihat dari perkembangan harga-harga saham yang diperdagangkan (Wijayaningsih, Rahayu, \& Saifi, 2015). Harga saham yang berada di pasar modal akan berubahubah dari waktu ke waktu serta mencerminkan keberhasilan pengelolaan perusahaan (Tumandung, Murni, \& N., 2017). Harga saham 
dapat dikatakan sebagai indikator keberhasilan perusahaan, dimana kekuatan pasar di bursa ditunjukkan dengan adanya transaksi jual beli saham di pasar modal (A. Surachim, Tanuatmodjo, \& Kussuma, 2016). Pemain saham atau investor harus memiliki informasi yang tepat mengenai harga saham perusahaan sebelum menanamkan modalnya. Informasi tersebut dipilih sebagai prospek investasi pemegang saham kedepannya, sehingga dengan adanya informasi tersebut dapat mempermudah investor dalam mengambil suatu keputusan agar sesuai dengan tujuan dan keinginan yang diharapkan atau agar mendapatkan dividen atau capital gain (Indiani \& Dewi, 2016).

Perkembangan dan pertumbuhan lembaga perbankan yang menjadi salah satu alasan para investor untuk tertarik berinvestasi di sektor bank (Winarsih, 2014). Semakin banyak investor yang ingin membeli atau menyimpan dananya dalam suatu saham, maka harga saham tentunya akan semakin naik. Begitu juga sebaliknya apabila semakin banyak investor yang akan menjual atau melepas suatu saham, maka harganya pun akan semakin bergerak turun (Takarini \& Putra, 2013). Permasalahan harga saham juga menjadi faktor yang sangat penting untuk diperhatikan di Indonesia karena sektor perbankan sempat jatuh dan mengalami penurunan kinerja dan dengan berjalannya waktu sektor perbankan harus membuktikan eksistensinya dalam kinerja dan pencapaian hasil yang cukup baik sehingga investor tertarik kembali membeli sahamnya (Wahyuningtyas \& Hartono, 2016) dan (Hutabarat, Veronica, \& Hutapea, 2016). Hal ini akan mendorong investor untuk semakin selektif dan lebih berhati-hati dalam mengambil keputusan berinvestasi saham di sektor perbankan (Noviantari, Wahyuni, \& Sinarwati, 2017).

Nilai suatu saham yang mencerminkan kekayaan perusahaan perbankan yang mengeluarkan saham tersebut, dimana perubahan atau fluktuasinya sangat ditentukan oleh kekuatan penawaran dan permintaan yang terjadi di Bursa. Semakin baik kinerja keuangan suatu perusahaan semakin tinggi laba usahanya dan semakin banyak keuntungan yang dapat dinikmati oleh pemegang saham, juga semakin besar kemungkinan harga saham akan naik (Rosita, Muharam, \& Haryanto, 2014). Salah satu cara dalam menilai sebuah perusahaan yang akan berpengaruh pada harga saham, investor dapat melakukan pengukuran kinerja keuangan. Kinerja bank dapat dinilai melalui berbagai macam variabel atau indikator, sumber utama variabel atau indikator yang dijadikan dasar penilaian adalah laporan keuangan perusahaan yang bersangkutan (I. M. Paramartha \& Darmayanti,
2017). Berdasarkan laporan keuangan inilah dapat dihitung sejumlah rasio keuangan yang lazim dijadikan dasar dari penilaian kinerja bank (Nino, Murni, \& Tumiwa, 2016).

Rasio keuangan dapat digunakan untuk mengukur tingkat kesehatan melalui laporan keuangan bank (Khalil \& Fuadi, 2016) yang diterbitkan setiap akhir periode, berupa gambaran posisi keuangan, perkembangan usaha (laporan laba rugi) dan besar risiko yang nantinya diinformasikan kepada pihak luar bank seperti bank sentral, masyarakat umum, dan investor (Sugari, Sunarko, \& Giyatno, 2015). Secara sederhana dapat dikatakan bahwa bank yang sehat adalah bank yang dapat menjalankan fungsifungsinya dengan baik. Penilaian kesehatan bank sangat penting karena bank mengelola dana dari masyarakat yang dipercayakan kepada bank (Pramana \& Artini, 2016). Kesehatan keuangan bank dianalisis dengan me-review data laporan keuangan, menghitung, membandingkan atau mengukur, menginterpretasikan dan memberi solusi (Parathon, Dzulkirom, \& Farah, 2012) sehingga dapat diketahui kondisi kesehatannya akan memudahkan bank itu sendiri untuk memperbaiki kesehatannya (Permana, 2012). Penilaian kesehatan bank dapat dilihat dari berbagai aspek yang bertujuan untuk mengetahui dan menentukan apakah bank tersebut dalam kondisi yang sehat, cukup sehat, kurang sehat atau tidak sehat (Gandawari, Areros, \& Keles, 2016).

Bank Indonesia sebagai bank sentral memiliki suatu kontrol terhadap bank-bank untuk mengetahui bagaimana keadaan keuangan serta kegiatan usaha masing-masing bank (Khoyimah, Lau, \& Suyatin, 2014). Kebijakan perbankan yang dikeluarkan dan dilaksanakan oleh Bank Indonesia pada dasarnya adalah ditujukan untuk menciptakan dan memelihara kesehatan, baik secara individu maupun perbankan secara sistem (Lasta, Arifin, \& Nuzula, 2014). Peraturan Bank Indonesia Nomor 13/1/PBI/2011 tanggal 5 Januari 2011 Pasal 1 Ayat 4 menjelaskan bahwa tingkat kesehatan bank adalah hasil penilaian suatu bank terhadap risiko dan kinerja bank berdasarkan Surat Edaran Bank Indonesia No. 13/24/DPNP tanggal 25 Oktober 2011 yang pada prinsipnya adalah tingkat kesehatan, pengelolaan bank, dan kelangsungan usaha bank merupakan tanggung jawab sepenuhnya dari manajemen bank.

Januari 2012 seluruh bank umum yang terdapat di Indonesia harus menggunakan pedoman penilaian tingkat kesehatan bank yang terbaru berdasarkan Peraturan Bank Indonesia (PBI) No.13/1/PBI/2011 tentang Penilaian Tingkat Kesehatan Bank Umum dengan metode RGEC (Risk Profile, Good Corporate 
Governance, Earning, Capital). Faktor- faktor penilaian dari masing-masing komponen RGEC adalah Profil Resiko (Risk Profile), Tata kelola perusahaan (Good Corporate Governance), Rentabilitas (Earnings), dan Permodalan (Capital).

Tujuan penelitian ini adalah (1) mengetahui gambaran tingkat kesehatan bank umum swasta nasional devisa periode 2012-2016 dengan menggunakan metode RGEC (Risk Profile, Good Corporate Governance, Earning, Capital) (2) mengetahui gambaran harga saham bank umum swasta nasional devisa periode 2012-2016 (3) mengetahui hubungan tingkat kesehatan bank umum swasta nasional devisa periode 2012-2016 dengan harga saham.

\section{KAJIAN PUSTAKA}

Pasar modal merupakan lembaga perantara antara pihak memiliki kelebihan dana dengan pihak yang sedang membutuhkan dana, dan sebagai lembaga yang mendorong terciptanya alokasi dana yang efisien (Tendelilin, 2010:26). Pasar modal memiliki peran yang penting bagi perekonomian suatu negara (Wardani \& Andarini, 2016) karena sebagai sarana bagi pendanaan usaha atau bagi perusahaan untuk mendapatkan dana dari masyarakat pemodal (investor) untuk dipergunakan untuk pengembangan usaha, ekspansi, penambahan modal kerja dan lain-lain serta sarana bagi masyarakat untuk berinvestasi pada instrumen keuangan seperti saham, obligasi, reksa dana, dan lain-lain (Panjaitan \& Wardani, 2014). Investasi di pasar modal sangat rentan dengan resiko. Begitupula halnya dalam berinvestasi saham. Keuntungan dan kerugian yang akan didapat oleh investor dipengaruhi oleh kemampuan investor dalam menganalisis pergerakan harga saham di pasar modal. Dalam melakukan analisis pergerakan harga saham, para pelaku pasar modal dihadapkan pada dua pendekatan dasar, yaitu analisis fundamental dan analisis ternikal (Husnan, 2010:307). Analisis teknikal dalam memprediksi arah pergerakan harga saham menggunakan data pasar historis (Tendelilin, 2010:392). Analisis fundamental dalam meakukan analisis penilaian saham dengan menggunakan estimasi dari nilai-nilai faktor fundamental yang dapat mempengaruhi harga saham dimasa depan (Husnan, 2010:307).

Menurut (Jogianto, 2003:88); (Elleuch, 2009) analisis fundamental berkaitan dengan kinerja keuangan perbankan karena analisis ini di anggap layak untuk digunakan ketika investor akan mengambil keputusan dalam memilih saham perusahaan mana yang akan dibeli untuk investor jangka panjang. (Hatta, 2015) juga sependapat dengan menyatakan bahwa investor menggunakan analisis fundamental dalam pengambilan keputusan investasinya. Kinerja keuangan dapat digunakan sebagai alat untuk mengukur operasional perbankan, apakah sudah berjalan sesuai dengan rencana dan aturan atau belum dan bahan evaluasi perbankan dalam suatu periode tertentu (DR.M.Dhanabhakyam \& M.Kavitha, 2012). Melalu kinerja keuangan seorang investor dapat mengetahui kesehatan perbankan, dapat mengetahui potensi perbankan dimasa mendatang dan dapat mengetahui bagaimana operasional dari perusahaan yang nantinya menjadi milik investor. Kinerja keuangan bank dapat dinilai melalui berbagai macam variabel atau indikator, sumber utama variabel atau indikator yang dijadikan dasar penilaian adalah laporan keuangan perusahaan yang bersangkutan (Atmaja, 2008); (I. M. Paramartha \& Darmayanti, 2017); (VanHorne \& Wachowicz, 2009). Laporan keuangan dapat mengukur tingkat kesehatan (Khalil \& Fuadi, 2016) karena bank berpereran mengelola dana dari masyarakat yang dipercayakan kepada bank (Kusumawardhani, 2014) yang diterbitkan setiap akhir periode, berupa gambaran posisi keuangan, perkembangan usaha (laporan laba rugi) dan besar risiko yang nantinya diinformasikan kepada pihak luar bank seperti bank sentral, masyarakat umum, dan investor (Sugari et al., 2015).

Kepercayaan dapat diperoleh dengan menjaga tingkat kesehatan bank (Dima, Dinca, \& Spulbar, 2014) dengan melakukan kegiatan operasional perbankan secara normal dan mampu memenuhi kewajiban dengan baik dengan caracara yang sesuai peraturan perbankan yang berlaku (D. G. D. A. Paramartha \& Mustanda, 2017). Bank Indonesia sebagai bank sentral Republik Indonesia yang berwenang untuk mengatur dan mengawasi bank-bank yang beroperasi di Indonesia mengeluarkan peraturan (Pramana \& Artini, 2016) yaitu penilaian tingkat kesehatan bank berdasarkan Surat Edaran Bank Indonesia No. 13/24/DPNP tanggal 25 Oktober 2011 perihal sistem penilaian tingkat kesehatan bank umum dengan metode RGEC. Indikator penilaian RGEC meliputi Profil Risiko (risk profile), Good Corporate Governance (GCG), Rentabilitas (earnings) dan Permodalan (capital). Metode RGEC inilah yang digunakan bank saat ini untuk mengidentifikasi permasalahan secara lebih dini, melakukan tindak lanjut perbaikan yang sesuai dan lebih cepat, serta menerapkan Good Corporate Governance (GCG) dan manajemen risiko yang lebih baik sehingga bank lebih tahan dalam menghadapi krisis.

$$
\text { Risk profile dihitung dengan }
$$
menggunakan rasio Non Performing Loan (NPL) untuk menghitung risiko kredit dan rasio Loan to Deposit Ratio (LDR) untuk menghitung risiko likuiditas yang diatur dalam PBI 
No.13/1/PBI/2011. Rasio Non Performing Loan (NPL) merupakan perbandingan antara kredit bermasalah terhadap total kredit. Menurut Peraturan Bank Indonesia No 6/10/PBI/2004 tentang Sistem Penilaian Tingkat Kesehatan Bank Umum, NPL lebih tinggi diatas 5\% maka semakin tinggi rasio ini maka akan semakin semakin buruk kualitas kredit bank yang menyebabkan jumlah kredit bermasalah semakin besar maka kemungkinan suatu bank dalam kondisi bermasalah semakin besar dan memungkinkan pencapaian laba semakin rendah (Nasser, 2003). Penurunan laba mengakibatkan dividen yang dibagikan juga semakin berkurang sehingga pertumbuhan tingkat harga saham bank akan mengalami penurunanRasio Loan to Deposit Ratio (LDR) merupakan perbandingan kredit yang diberikan terhadap dana pihak ketiga. Batas aman dari LDR suatu bank adalah sekitar $80 \%$. Namun batas maksimal LDR adalah $110 \%$ (Kasmir, 2014). Semakin tinggi LDR menunjukkan semakin tinggi dana yang disalurkan kepada pihak ketiga. Semakin tinggi rasio ini maka semakin rendah pula kemampuan likuiditas bank, karena jumlah dana yang diperlukan untuk membiayai kredit menjadi semakin besar. Sebaliknya, semakin rendah rasio LDR menunjukkan kurangnya efektifitas bank dalam menyalurkan kredit. Jadi banyaknya kredit yang diberikan oleh bank kepada masyarakat harus diimbangi dengan kemampuan bank tersebut untuk mengembalikan dana itu. Menurut teori (Dendawijaya, 2005:116) dengan keseimbangan kemampuan ini maka rasio LDR akan tetap terjaga, serta masyarakat dan investor akan semakin percaya bahwa bank tersebut dalam kondisi sehat sehingga pada akhirnya harga saham juga akan meningkat.

Metode dalam penilaian good corporate governance dianalisis berdasarkan Surat Edaran Bank Indonesia No.15/15/DPNP tahun 2013 tentang penilaian good corporate governance yang mewajibkan bank secara berkala melakukan penilaian sendiri (self assessment) secara komprehensif terhadap kecukupan pelaksanaan good corporate governance. Dengan penerapan GCG yang mencakup adanya transparansi atau pengungkapan informasi penting dalam laporan tahunan dan laporan keuangan perseroan kepada pemegang saham, maka dapat meningkatkan kepercayaan investor akan kualitas informasi keuangan yang dipublikasikan perseroan. (Chtourou, Bédard, \& Courteau, 2001) yang menguji apakah praktek Corporate Governance mempunyai pengaruh positif terhadap kualitas informasi keuangan yang dipublikasikan perusahaan. Hal tersebut sejalan dengan peneliti (Ngoc, Tuan, \& Mai, 2013) membuktikan adanya hubungan yang positif antara penerapan corporate governance dengan berkurangnya kecurangan (fraud) pada laporan keuangan (financial reporting) yang dapat meningkatkan kualitas laporan keuangan yang dipublikasikan perusahaan. Para investor tidak begitu saja membeli saham sebelum melakukan penilaian terlebih dahulu terhadap emiten (perusahaan yang mengeluarkan saham).

Earning dihitung dengan menggunakan rasio return on asset (ROA) dan net interest margin (NIM) berdasarkan Surat Edaran Bank Indonesia No.13/24/DPNP tanggal 25 Oktober 2011. Rasio Return on Asset (ROA) merupakan perbandingan laba sebelum pajak bank terhadap aset. Bank Indonesia sebagai otoritas moneter menetapkan ROA sebesar 1,5\% agar bank tersebut dapat dikatakan dalam kondisi sehat (Zulhelmi \& Utomo, 2013). Menurut (Astuti, 2004:37) semakin tinggi nilai Return on Assets (ROA) maka semakin baik kinerja manajemen dalam menghasilkan laba dan semakin edektif pula perusahaan. Return on Assets (ROA) yang mempengaruhi kebijakan para investor atas investasi yang dilakukan. Kemampuan perusahaan untuk menghasilkan laba akan dapat menarik para investor untuk menanamkan dananya guna memperluas usahanya, sebaliknya tingkat profitabilitas yang rendah akan menyebabkan para investor menarik dananya (D. H. A. Surachim \& IZFS, 2016)

Rasio Net Interest Margin (NIM) merupakan perbandingan antara pendapatan bunga bersih terhadap aktiva produktif. Net Interest Margin (NIM) yang tinggi menunjukkan bank semakin efektif dalam penempatan aktiva perusahaan dalam bentuk kredit, sehingga pendapatan bunga bank meningkat. Informasi ini membuat investor tertarik berinvestasi pada saham perbankan dan berdampak pada peningkatan harga sahamnya (Kurniadi, 2012).

Capital dihitung dengan menggunakan rasio CAR Berdasarkan SE BI No.13/24/DPNP tanggal 25 Oktober 2011. Rasio Capital Adequacy Ratio (CAR) merupakan perbandingan modal bank dengan aktiva tertimbang. Bank yang dianggap sehat adalah bank yang memiliki Capital Adequacy Ratio (CAR) di atas $8 \%$.. Menurut teori (Suardana, 2009) menyatakan semakin tinggi Capital Adequacy Ratio (CAR) maka harga saham akan meningkatkan sebaliknya bila CAR yang rendah akan menurunkan harga saham sehingga menurut penelitian (Praditasari, 2009) dan (Abdullah \& L.Suryanto, 2004) CAR berpengaruh positif dan signifikan terhadap perubahan harga saham. Hal ini menunjukkan bahwa investor cenderung memperhatikan aspek permodalan CAR dalam menentukan dan membeli harga saham perbankan. 


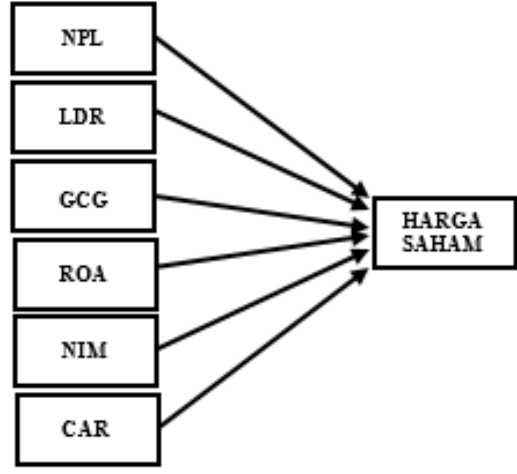

GAMBAR 2.1 PARADIGMA PENELITIAN

\section{METODE PENELITIAN}

Penelitian ini menganalisis mengenai menganalisis tingkat kesehatan bank dengan menggunakan metode RGEC (Risk Profile, Good Corporate Governance, Earnings, Capital) dan pengaruhnya terhadap harga saham pada bank umum swasta nasional devisa. Adapun yang menjadi variabel bebas atau independent variabel dalam penelitian ini yaitu tingkat kesehatan bank yang diukur dengan komponen RGEC (X) kemudian yang menjadi variabel terikat atau dependent variabel yaitu harga saham (Y). Objek penelitian ini adalah laporan keuangan, self assesment good corporate governance, dan harga saham BUSN Devisa yang terdaftar di Bursa Efek Indonesia (BEI) selama lima tahun berturut-turut. Teknik sampling dalam penelitian ini menggunakan purposive sampling dan diperoleh lima BUSN devisa. Metode yang digunakan dalam penelitian ini adalah metode deskriptif dan verifikatif. Data yang digunakans adalah data sekunder dari masing-masing BUSN devisa periode 2012-2016.

\section{HASIL PENELITIAN DAN PEMBAHASAN}

Pengujian dalam penelitian ini menggunakan Uji $\mathrm{F}$ dengan tujuan untuk mengetahui pengaruh variabel-variabel independent, yaitu komponen RGEC dengan variabelnya $\mathrm{NPL}\left(\mathrm{X}_{1}\right)$, LDR $\left(\mathrm{X}_{2}\right), \mathrm{GCG}\left(\mathrm{X}_{3}\right)$, ROA $\left(\mathrm{X}_{4}\right)$, NIM $\left(\mathrm{X}_{5}\right)$, CAR $\left(\mathrm{X}_{6}\right)$ terhadap variabel dependent, yaitu harga saham (Y) dengan menggunakan uji keberartian regresi, tabel berikut akan menunjukan hasil Uji $F$ dalam penelitian ini,

TABEL 4.13

HASIL PENGUJIAN UJI F ANOXA:

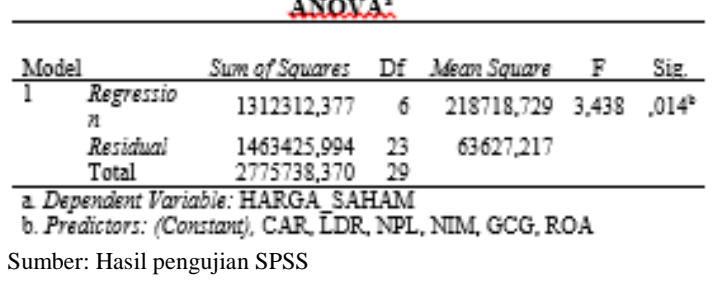

Pada Tabel 4.13 menunjukan bahwa hasil $F_{\text {hitung }}$ pada penelitian ini adalah sebesar 3,438 sedangkan hasil untuk $\mathrm{F}_{\text {tabel }}$ adalah 3,32 maka dengan begitu nilai $F_{\text {hitung }}$ lebih besar dari $F_{\text {tabel }}$ atau 3,438>3,32 dengan demikian menunjukan bahwa $\mathrm{H}_{\mathrm{o}}$ diterima. Nilai signifikansi dari $F_{\text {hitung }}$ adalah 0,014 yang menunjukan bahwa nilai tersebut lebih kecil dari taraf nyata $5 \%$ atau $0,014<0,05$. Hal ini membuktikan bahwa model regresi dapat digunakan untuk mengambil kesimpulan mengenai pengaruh komponen RGEC terhadap Harga Saham.

Model regresi yang digunakan dalam penelitian ini adalah regresi linier multiple yang bertujuan untuk meramalkan naik turunnya variabel dependent, dengan enam variabel independent sebagai faktor predictor yang dimanipulasi. Tabel di bawah ini akan menunjukan hasil uji regresi linear multiple dengan penggunaan persamaan regresi multiple $\left(\mathrm{Y}=\mathrm{a}+\beta \mathrm{X}_{1}+\beta \mathrm{X}_{2}+\beta \mathrm{X}_{3}+\beta \mathrm{X}_{4}+\beta \mathrm{X}_{5}+\beta \mathrm{X}_{6}\right)$

\section{TABEL 4.12}

\section{UJI REGRESI LINEAR MULTIPLE}

\begin{tabular}{|c|c|c|c|c|c|c|}
\hline \multicolumn{7}{|c|}{ Coefficienta ${ }^{2}$} \\
\hline \multirow{2}{*}{\multicolumn{2}{|c|}{ Model }} & \multicolumn{2}{|c|}{$\begin{array}{l}\text { Unstandaratized } \\
\text { Coefficients }\end{array}$} & \multirow{2}{*}{$\begin{array}{c}\begin{array}{c}\text { Standiaraized } \\
\text { Coefficients }\end{array} \\
\text { Betz }\end{array}$} & \multirow[b]{2}{*}{$\mathrm{T}$} & \multirow[b]{2}{*}{ Sig. } \\
\hline & & & $\begin{array}{c}\text { Stdl. } \\
\text { Enror }\end{array}$ & & & \\
\hline \multirow[t]{7}{*}{1} & $\begin{array}{c}\text { (Constan } \\
t)\end{array}$ & $-1160,019$ & 919,797 & & $-1,261$ & .220 \\
\hline & NPL & 103,141 & 43,938 & .424 & 2,347 & .028 \\
\hline & LDR & 14,459 & 7,194 & 376 & 2,010 & .056 \\
\hline & GCG & $-130,357$ & 135,487 &,- 178 &,- 962 & .346 \\
\hline & ROA & 160,972 & 61,669 & .590 & 2,610 & .016 \\
\hline & NMM & $-1,551$ & 67,941 & -.005 &,- 023 & .982 \\
\hline & CAR & 2,198 & 17,037 & .022 & .129 & .898 \\
\hline
\end{tabular}

Pada Tabel 4.12 dapat dilihat dalam kolom B nilai konstanta dan nilai koefisien regresi linear multiple untuk masing-masing variabel independent. Berdasarkan nilai-nilai di atas dapat ditentukan model regresi linear multipel yang dinyatakan dalam bentuk persamaan, sebagai berikut:

$\mathrm{Y}=(-1160,019)+103,141 \mathrm{NPL}+14,459 \mathrm{LDR}-$ $130,357 \mathrm{GCG}+160,972 \mathrm{ROA}-1,551 \mathrm{NIM}+$ 2,198CAR

a. Nilai konstanta $-1160,019$ ini berarti bahwa jika nilai variabel NPL, LDR, GCG, ROA, NIM, CAR tidak mengalami perubahan atau sama dengan nol maka nilai harga saham Rp 1160,019

b. Nilai koefisien regresi NPL $\left(\mathrm{X}_{1}\right)$

Nilai koefisien NPL sebesar 103,141, nilai ini menunjukan bahwa setiap peningkatan NPL sebesar $1 \%$ maka akan menyebabkan peningkatan harga saham sebesar Rp 103,141 dengan asumsi variabel NPL bernilai konstan atau nol.

c. Nilai koefisien regresi LDR $\left(\mathrm{X}_{2}\right)$

Nilai koefisien LDR sebesar 14,459 , nilai ini menunjukan bahwa setiap peningkatan LDR sebesar $1 \%$ maka akan menyebabkan 
peningkatan harga saham sebesar Rp 14,459 dengan asumsi variabel LDR bernilai konstan atau nol.

d. Nilai koefisien regresi GCG $\left(\mathrm{X}_{3}\right)$

Nilai koefisien GCG sebesar -130,357, nilai ini menunjukan bahwa setiap peningkatan GCG sebesar $1 \%$ maka akan menyebabkan punurunan harga saham sebesar Rp 130,357 dengan asumsi variabel GCG bernilai konstan atau nol.

e. Nilai koefisien regresi $\mathrm{ROA}\left(\mathrm{X}_{4}\right)$

Nilai koefisien ROA sebesar 160,972, nilai ini menunjukan bahwa setiap peningkatan ROA sebesar $1 \%$ maka akan menyebabkan peningkatan harga saham sebesar Rp 160,972 dengan asumsi variabel ROA bernilai konstan atau nol.

f. Nilai koefisien regresi NIM $\left(\mathrm{X}_{5}\right)$

Nilai koefisien NIM sebesar -1,551, nilai ini menunjukan bahwa setiap peningkatan NIM sebesar $1 \%$ maka akan menyebabkan penurunan harga saham sebesar Rp 1,551 dengan asumsi variabel NIM bernilai konstan atau nol.

g. Nilai koefisien regresi $\mathrm{CAR}\left(\mathrm{X}_{6}\right)$

Nilai koefisien CAR sebesar 2,198, nilai ini menunjukan bahwa setiap peningkatan CAR sebesar $1 \%$ maka akan menyebabkan peningkatan harga saham sebesar Rp 2,198 dengan asumsi variabel CAR bernilai konstan atau nol.

Sedangkan untuk menguji keberartian koefesien regresi dilakukan melalui uji t dengan cara membandingkan antara thitung dengan ttabel dari koefisien regresi tiap variabel independen secara statistik. Tabel berikut merupakan hasil Uji $\mathrm{T}$ untuk mengetahui pengaruh antara menguji komponen RGEC terhadap harga saham,

\section{TABEL 4.14}

HASIL PENGUJIAN UJI t

\begin{tabular}{|c|c|c|c|c|c|c|}
\hline \multirow{3}{*}{\multicolumn{2}{|c|}{ Model }} & \multicolumn{3}{|c|}{ Cosfficienta ${ }^{2}$} & \multirow{3}{*}{$\mathrm{T}$} & \multirow[b]{3}{*}{ Sig. } \\
\hline & & \multicolumn{2}{|c|}{$\begin{array}{l}\text { Unstandaratised } \\
\text { Coefficients }\end{array}$} & \multirow{2}{*}{$\begin{array}{c}\begin{array}{c}\text { Standiarized } \\
\text { Coefficients }\end{array} \\
\text { Beta } \\
\end{array}$} & & \\
\hline & & B & Std. & & & \\
\hline \multirow[t]{7}{*}{1} & (Constan & $-1160,019$ & 919,797 & & $-1,261$ & .220 \\
\hline & NPL & 103,141 & 43,938 & .424 & 2,347 & .028 \\
\hline & LDR & 14,459 & 7,194 & .376 & 2,010 & .056 \\
\hline & GCG & $-130,357$ & 135,487 &,- 178 &,- 962 & 346 \\
\hline & $\mathrm{ROA}$ & 160,972 & 61,669 & .590 & 2,610 & .016 \\
\hline & NMM & $-1,551$ & 67,941 & -.005 &,- 023 & 982 \\
\hline & CAR & 2,198 & 17,037 & .022 & 129 & .898 \\
\hline
\end{tabular}

Pada tabel 4.14 dari hasil perhitungan uji t dapat dibuktikan bahwa:

a. Keberartian koefisien regresi Non Performing Loan (NPL) terhadap harga saham

Hasil uji $t$ menunjukkan bahwa nilai $t_{\text {hitung }}$ sebesar 2,347, sedangkan nilai $t_{\text {tabel }}$ dalam penelitian ini adalah 2,05183, dengan demikian maka $t_{\text {hitung }}$ lebih besar dari $t_{\text {tabel }}$ atau $2,347>2,05183$. Adapun nilai signifikansi dari $\mathrm{t}_{\text {hitung }}$ adalah 0,028 yang berarti nilai tersebut lebih kecil dari taraf nyata $5 \%$, atau $0,028<0,05$ dengan demikian dapat dibuktikan bahwa $\mathrm{H}_{01}$ ditolak dan $\mathrm{Ha}_{1}$ diterima, yang berarti Non Performing Loan (NPL) berpengaruh terhadap harga saham. Arah regresi bertanda positif menunjukan bahwa Non Performing Loan (NPL) memiliki hubungan yang searah dengan Harga Saham.

b. Keberartian koefisien regresi Loan to Deposit Ratio (LDR) terhadap harga saham

Hasil uji $\mathrm{t}$ menunjukkan bahwa nilai $t_{\text {hitung }}$ sebesar 2,010, sedangkan nilai $t_{\text {tabel }}$ dalam penelitian ini adalah 2,05183, dengan demikian maka $t_{\text {hitung }}$ lebih kecil dari $t_{\text {tabel }}$ atau $2,010<2,05183$. Adapun nilai signifikansi dari $\mathrm{t}_{\text {hitung }}$ adalah 0,056 yang berarti nilai tersebut lebih besar dari taraf 5\%, atau 0,056>0,05 dengan demikian dapat dibuktikan bahwa $\mathrm{H}_{02}$ diterima dan $\mathrm{Ha}_{2}$ ditolak, yang berarti Loan to Deposit Ratio (LDR) tidak berpengaruh terhadap harga saham. Arah regresi bertanda positif menunjukan bahwa Loan to Deposit Ratio (LDR) memiliki hubungan yang searah dengan harga saham.

c. Keberartian koefisien regresi Good Corporate Governance (GCG) terhadap harga saham Hasil uji $\mathrm{t}$ menunjukkan bahwa nilai $\mathrm{t}_{\text {hitung }}$ sebesar -0,962, sedangkan nilai $t_{\text {tabel }}$ dalam penelitian ini adalah 2,05183, dengan demikian maka - $t_{\text {hitung }}$ lebih kecil dari $-t_{\text {tabel }}$ atau $0,962<2,05183$. Adapun nilai signifikansi

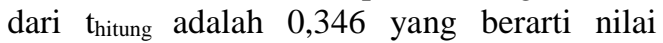
tersebut lebih besar dari taraf nyata $5 \%$, atau 0,346>0,05 dengan demikian dapat dibuktikan bahwa $\mathrm{H}_{03}$ diterima dan $\mathrm{Ha}_{3}$ ditolak yang berarti Good Corporate Governance (GCG) tidak berpengaruh terhadap harga saham. Arah regresi bertanda negatif menunjukan bahwa Good Corporate Governance (GCG) memiliki hubungan yang berlawanan arah dengan harga saham.

d. Keberartian koefisien regresi Return on asset (ROA) terhadap harga saham

Hasil uji $t$ menunjukkan bahwa nilai $t_{\text {hitung }}$ sebesar 2,610, sedangkan nilai $t_{\text {tabel }}$ dalam penelitian ini adalah 2,05183, dengan demikian maka $t_{\text {hitung }}$ lebih besar dari $t_{\text {tabel }}$ atau $2,610>2,05183$. Adapun nilai signifikansi dari $\mathrm{t}_{\text {hitung }}$ adalah 0,016 yang berarti nilai tersebut lebih kecil dari taraf nyata $5 \%$, atau $0,016<0,05$ dengan demikian dapat dibuktikan bahwa $\mathrm{H}_{04}$ ditolak dan $\mathrm{Ha}_{4}$ diterima, yang berarti Return on asset (ROA) berpengaruh terhadap harga saham. Arah regresi bertanda positif menunjukan bahwa Return on asset (ROA) memiliki hubungan yang searah dengan harga saham. 
e. Keberartian koefisien regresi Net interest margin (NIM) terhadap harga saham

Hasil uji $t$ menunjukkan bahwa nilai $t_{\text {hitung }}$ sebesar -0,023, sedangkan nilai $t_{\text {tabel }}$ dalam penelitian ini adalah 2,05183, dengan demikian maka - $t_{\text {hitung }}$ lebih kecil dari - $t_{\text {tabel }}$ atau $0,023<2,05183$. Adapun nilai signifikansi dari $t_{\text {hitung }}$ adalah 0,982 yang berarti nilai tersebut lebih besar dari taraf nyata $5 \%$, atau 0,982>0,05 dengan demikian dapat dibuktikan bahwa $\mathrm{H}_{05}$ diterima dan $\mathrm{H}_{\mathrm{a} 5}$ ditolak, yang berarti Net interest margin (NIM) tidak berpengaruh terhadap harga saham. Arah regresi bertanda negatif menunjukan bahwa Net interest margin (NIM) memiliki hubungan yang berlawanan arah dengan harga saham.

f. Keberartian koefisien regresi Capital Adequacy Ratio (CAR) terhadap harga saham Hasil uji $\mathrm{t}$ menunjukkan bahwa nilai $\mathrm{t}_{\text {hitung }}$ sebesar 0,129, sedangkan nilai $t_{\text {tabel }}$ dalam penelitian ini adalah 2,05183, dengan demikian maka thitung lebih kecil dari $t_{\text {tabel }}$ atau $0,129<2,05183$. Adapun nilai signifikansi dari $\mathrm{t}_{\text {hitung }}$ adalah 0,898 yang berarti nilai tersebut lebih besar dari taraf nyata $5 \%$, atau 0,898>0,05, dengan demikian dapat dibuktikan bahwa $\mathrm{H}_{06}$ diterima dan $\mathrm{H}_{\mathrm{a} 6}$ ditolak yang berarti Capital Adequacy Ratio (CAR) tidak berpengaruh terhadap harga saham. Arah regresi bertanda positif menunjukan bahwa Capital Adequacy Ratio (CAR) memiliki hubungan yang searah dengan harga saham.

Hasil penelitian ini sejalan dengan teori (Nasser, 2003) yang menyataan rasio nonperforming loan menunjukan bahwa kemampuan manajemen bank dalam mengelola kredit bermasalah yang diberikan oleh bank. Sehingga semakin tinggi rasio ini maka akan semakin semakin buruk kualitas kredit bank yang menyebabkan jumlah kredit bermasalah semakin besar maka kemungkinan suatu bank dalam kondisi bermasalah semakin besar dan memungkinkan pencapaian laba semakin rendah. Kredit dalam hal ini adalah kredit yang diberikan kepada pihak ketiga tidak termasuk kredit kepada bank lain. Penurunan laba mengakibatkan dividen yang dibagikan juga semakin berkurang sehingga pertumbuhan tingkat harga saham bank akan mengalami penurunan serta penelitian yang dilakukan oleh (Harahap \& Hairunnisah, 2017) dan (Panjaitan \& Wardani, 2016) yang menyatakan bahwa NPL berpengaruh positif terhadap harga saham. Hal ini disebabkan karena kenaikan rata-rata presentase perbankan di Indonesia masih berada pada taraf yang wajar, yaitu di bawah 5\% (ketentuan Bank Indonesia) dan setiap kenaikan presentase NPL searah dengan kenaikan harga saham sehingga para investor tidak mempermasalahkan untuk tetap berinvestasi di dunia perbankan.

Hasil penelitian ini berlawanan dengan teori yang ada yang menyatakan bahwa semakin tinggi rasio LDR semakin rendah pula kemampuan likuiditas suatu bank sehinga risiko dalam berinvestasi semakin tinggi pula karena perusahaan perbankan tidak memiliki kemampuan untuk membayar kembali kewajiban atas dana nasabah atau pihak ketiga (Siamat, 2005). Dan akan mengurangi kepercayaan investor untuk berinvestasi kepada bank tersebut. Hal ini akan berdampak pada berkurangnya permintaan terhadap saham perusahaan. Dengan berkurangnya permintaan akan saham perusahaan tersebut, maka hal ini akan berpengaruh terhadap harga sahamnya. Hasil statistik memberikan makna bahwa informasi likuiditas yang digambarkan oleh LDR yang dipublikasikan dalam laporan keuangan kurang dijadikan oleh investor dalam menganalisis informasi keuangan (Sari, 2013). Hasil penelitian ini sejalan dengan penelitian yang dilakukan oleh (Takarini \& Putra, 2013); (Ulfa \& Budiyanto, 2014) yang menyatakan bahwa LDR tidak berpengaruh terhadap harga saham. Hasil penelitian ini juga didukung oleh teori dari (Darsono \& Ashari, 2005) yang menyatakan bahwa likuiditas memiliki pengaruh positif terhadap harga saham, dimana jika likuiditas meningkat maka harga saham meningkat sedangkan jika likuiditas menurun maka harga saham pun ikut menurun.

Hasil penelitian ini berlawangan dengan hasil penelitian (Chtourou et al., 2001) dan (Ngoc et al., 2013) melainkan sejalan dengan penelitian yang dilakukan oleh (Ramadhani, 2009) dan (Bangun \& Jeffry, 2008) yang menyatakan bahwa variabel Good Corporate Governance (GCG) berpengaruh negatif terhadap harga saham karena pengaruh Good Corporate Governance (GCG) tidak dapat dirasakan secara langsung oleh perusahaan, sehingga kurang direspon oleh investor dalam pengambilan keputusan investasi saham melainkan dalam jangka panjang baru dapat terlihat.

Hasil penelitian ini sejalan dengan teori (Astuti, 2004:37) dan sejalan dengan penelitian yang dilakukan oleh (Polii, Saerang, \& Mandagie, 2014) dan (Lestari, 2015) yang menyatakan bahwa ROA berpengaruh positif terhadap harga saham. Yang menyatakan apabila suatu perusahaan mempunyai ROA yang tinggi maka perusahaan tersebut mampu menghasilkan laba yang tinggi pula, dengan laba yang tinggi maka semakin tinggi pula besarnya deviden yang akan dibagikan kepada investor. Kondisi seperti inilah yang menjadi daya tarik masyarakat untuk memiliki saham perusahaan tersebut. Selain itu, dapat diketahui juga bahwa disamping 
memperoleh keuntungan dari capital gain investor juga memperhatikan tingkat pencapaian profitabilitas bank dengan melihat dari besarnya rasio return on assets untuk memutuskan investasi dalam bentuk saham. Dari pengaruh yang baik ini dapat diketahui bahwa manajemen perusahaan dapat menggunakan asset perusahaan dengan baik, peningkatan sales yang lebih besar dari peningkatan biaya, dan meningkatnya return yang akan diterima investor. Pengaruh ini dapat meningkatkan harga saham dipasaran dan menarik investor untuk menginvestasikan modalnya di perusahaan tersebut (Susilowati \& Utiyati, 2016).

Hasil penelitian ini berlawanan dengan teori yang ada yang menyatakan bahwa Net Interest Margin (NIM) yang tinggi menunjukkan bank semakin efektif dalam penempatan aktiva perusahaan dalam bentuk kredit, sehingga pendapatan bunga bank meningkat. Informasi ini membuat investor tertarik berinvestasi pada saham perbankan dan berdampak pada peningkatan harga sahamnya (Kurniadi, 2012). Melainkan hasil penelitian ini sejalan dengan penelitian yang dilakukan oleh (Indiani \& Dewi, 2016); Chrisna (2009); Wijayanti (2010) yang menyatakan bahwa NIM tidak berpengaruh terhadap harga saham. Hasil penelitian ini menunjukkan bahwa pasar saham tidak bereaksi terhadap informasi rentabilitas perusahaan perbankan yang diukur dengan menggunakan NIM. Informasi NIM perbankan setiap tahun tidak mampu memberikan sinyal bagi investor untuk mengambil keputusan investasi saham berpengaruh pada naiknya harga saham perusahaan.

Secara teori, CAR yang tinggi akan meningkatkan harga saham sedangkan sebaliknya CAR yang rendah akan menurunkan harga saham (Suardana, 2009). Pada penelitian ini ditemukan hasil bahwa CAR tidak memiliki pengaruh kepada harga saham perbankan. Hal ini dapat dijelaskan bahwa meskipun CAR dalam penelitian ini memiliki nilai yang berada diatas batas minimum yang ditentukan oleh BI tidak membuat CAR dapat memengaruhi perubahan harga saham karena investor lebih melihat pada faktor eksternal perusahaan dalam menilai harga saham perusahaan. Investor menganggap bahwa rasio CAR belum cukup baik untuk menggambarkan return yang sepadan dengan risiko yang akan ditanggungnya (Winarsa, 2010). Hal tersebut menyebabkan investor menjadi kurang memperhatikan CAR dalam berinvestasi, sehingga CAR tidak berpengaruh terhadap harga saham sejalan dengan penelitian yang dilakukan oleh (Rahayu, 2014) dan (Sambul, Murni, \& Tumiwa, 2016).

\section{KESIMPULAN DAN REKOMENDASI}

Berdasarkan uraian teori dan hasil penelitian yang telah dilakukan dengan menggunakan analisis deskripsi dan verifikatif serta uji regresi liniear multiple antara tingkat kesehatan bank dengan menggunakan RGEC terhadap harga saham pada Bank Umum Swasta Nasional Devisa yang terdaftar di BEI periode 2012-2016, dapat ditarik kesimpulan bahwa hasil uji t menunjukan bahwa Non Performing Loan (NPL) terhadap harga saham, diperoleh hasil bahwa NPL berpengaruh positif terhadap harga saham, ini menunjukan bahwa risk profile diukur dengan NPL mengalami peningkatan maka harga saham akan meningkat. Loan to Deposit Ratio (LDR) terhadap harga saham, diperoleh hasil bahwa LDR tidak berpengaruh terhadap harga saham. Arah regresi bertanda positif menunjukan bahwa LDR memiliki hubungan yang searah dengan harga saham.

Good Corporate Governance (GCG) terhadap harga saham, diperoleh hasil bahwa GCG tidak berpengaruh terhadap harga saham, ini menunjukkan bahwa apabila GCG perusahaan mengalami penurunan maka tidak akan berpengaruh pada naiknya harga saham perusahaan. Return on asset (ROA) terhadap harga saham, diperoleh hasil bahwa ROA berpengaruh positif terhadap harga saham, ini menunjukkan bahwa earning diukur dengan ROA mengalami peningkatan maka harga saham akan meningkat. Net interest margin (NIM) terhadap harga saham, diperoleh hasil bahwa NIM tidak berpengaruh terhadap harga saham, ini menunjukkan bahwa apabila NIM mengalami penurunan maka tidak akan berpengaruh pada naiknya harga saham perusahaan. Capital Adequacy Ratio (CAR) terhadap harga saham, diperoleh hasil bahwa CAR tidak berpengaruh terhadap harga saham. Arah regresi bertanda positif menunjukan bahwa CAR memiliki hubungan yang searah dengan harga saham.

\section{DAFTAR PUSTAKA}

Abdullah, F., \& L.Suryanto. (2004). Saham Perusahaan Perbankan Yang Terdaftar Di Bursa Efek Jakarta. Jurnal Studi Manajemen \& Organisasi, 1(2), 1-8.

Astuti, D. (2004). Manajemen Keuangan Perusahaan. (G. Indonesia, Ed.). Jakarta.

Atmaja, L. S. (2008). Manajemen Keuangan. Yogyakarta: Penerbit Andi.

Bangun, P., \& Jeffry. (2008). Pengaruh Good Corporate Covernance Dan Kinerja Keuangan Terhadap Harga Saham. Jurnal Akuntansi, 8(1), 85-106.

Chtourou, S. M., Bédard, J., \& Courteau, L. (2001). Corporate Governance And Earnings Management, 4(April), 1-35. 
Dendawijaya, L. (2005). Manajemen Perbankan. Jakarta: Ghalia Indonesia.

Dima, B., Dinca, M. S., \& Spulbar, C. (2014). Financial Nexus: Efficiency And Soundness In Banking And Capital Markets. Journal Of International Money And Finance, 47, $100-124$

Https://Doi.Org/10.1016/J.Jimonfin.2014.0 5.002

Dr.M.Dhanabhakyam, \& M.Kavitha. (2012). Financial Performance Of Selected Public Sector Banks In India. International Journal Of Multidisciplinary Research, 2(1), 225-269.

Elleuch, J. (2009). Fundamental Analysis Strategy And The Prediction Of Stock Returns”. International Research Journal Of Finance And Economics. Faculty of Economics And Management Sciences, University Of Sfax, Tunisia, (30), 95-108.

Gandawari, Y., Areros, W. A., \& Keles, D. (2016). Analisis Tingkat Kesehatan Bank Menggunakan Metode Rgec Pada Pt. Bank Sulutgo Periode 2014-2016.

Hakmi, S. S., Rahayu, S. M., Administrasi, F. I., \& Brawijaya, U. (2017). Analisis Fundamental Dengan Pendekatan Price Earning Ratio ( Per ) Untuk Menilai Kewajaran Harga Saham Sebagai Dasar Pengambilan Keputusan Investasi ( Studi Pada Subsektor Semen Yang Listing Di Bursa Efek Indonesia Pada Tahun 20132015 ). Jurnal Administrasi Bisnis (Jab), 49(2), 96-102.

Harahap, D. A., \& Hairunnisah, A. I. (2017). Pengaruh Npl, Ldr, Gcg, Nim , Roa, Roe , Car ,Bopo Terhadap Harga Saham Pada Perusahaan Perbankan Yang Terdaftar Di Bursa Efek Indonesia Dari Tahun 2010 2014., 6(1), 22-40.

Hatta, I. S. I. H. (2015). Pengaruh Kinerja Keuangan Terhadap Harga Saham 10 Bank Terkemuka Di Indonesia. Jurnal Akuntansi, $\operatorname{Xix}(2), 179-191$.

Husnan, S. (2010). Dasar-Dasar Teori Portofolio \& Analisis Sekuritas (Keempat). Yogyakarta: Upp Stim Ykpn.

Hutabarat, F. M., Veronica, D., \& Hutapea, J. J. H. (2016). Understanding Capital Asset Pricing Model Analysis In Determining Risk And Return Of Companies At Cosmetic And Household Sub Sector At Indonesia Stock Exchange. Semnas Fekon 2016, 437-441.

Indiani, N. P. L., \& Dewi, S. K. S. (2016). Pengaruh Variabel Tingkat Kesehatan Bank Terhadap Harga Saham Perbankan Di Bursa Efek Indonesia. E-Jurnal Manajemen Unud, 5(5), 2756-2785.
Jogianto, H. (2003). Teori Portofolio Dan Analisis Investasi. Yogyakarta: Bpfe.

Kasmir. (2014). Bank Dan Lembaga Keuangan Lainnya (Edisi Revi). Jakarta: Pt Raja Grafindo.

Khalil, M., \& Fuadi, R. (2016). Analisis Penggunaan Metode Risk Profile , Good Corporate Governance, Earning , And Capital ( Rgec ) Dalam Mengukur Kesehatan Bank Pada Bank Umum Syariah Di Indonesia Periode 2012-2014 Keywords : Rgec Method, Risk Base Bank Rating. Ijurnal Ilmiah Mahasiswa Ekonomi Akuntansi, 1(1).

Khoyimah, F., Lau, E. A., \& Suyatin. (2014). Analisis Kesehatan Bank Pada Pt. Bank Tabungan Negara (Persero) Tbk.

Kurniadi, R. (2012). Pengaruh Car, Nim, Ldr Terhadap Return Saham Perusahaan Perbankan Indonesia. Accounting Analysis Journal, 1(1).

Kusumawardhani, A. (2014). Analisis Perbandingan Tingkat Kesehatan Bank Dengan Menggunakan Metode Camels Dan Rgec Pada Pt. Bank Xxx Periode 20082011. Jurnal Ekonomi Bisnis, 19(3), 1-7.

Lasta, H. A., Arifin, Z., \& Nuzula, N. F. (2014). Analisis Tingkat Kesehatan Bank Dengan Menggunakan Pendekatan Rgec ( Risk Profile , Good Corporate Governance , Earnings , Capital ) ( Studi Pada Pt Bank Rakyat Indonesia , Tbk Periode 2011-2013 ). Jurnal Administrasi Bisnis (Jab), 13(2), $1-10$.

Lestari, S. D. (2015). Pengaruh Capital, Asset, Earning Dan Liquidity Terhadap Perubahan Harga Saham Bank. Jurnal Ilmu \& Riset Manajemen, 4(9), 1-22.

Nasser, E. M. (2003). Perbandingan Kinerja Bank Pemerintah Dan Bank Swasta Dengan Rasio Camel Serta Pengaruhnya Terhadap Harga Saham. Media Riset Akuntansi, Auditing Dan Informasi, 3(3), 217-236.

Ngoc, L. T. B., Tuan, L. T., \& Mai, L. H. (2013). Corporate Governance And Stock Prices. Tap Chí Khoa Hoc Đhsp Tphcm, 144-152.

Nino, Y., Murni, S., \& Tumiwa, J. R. (2016). Analisis Ukuran Perusahaan, Struktur Modal, Non Performing Loan (Npl), Capital Adequacy Ratio (Car), Dan Return On Equity (Roe) Terhadap Harga Saham Perusahaan Perbankan Pada Indeks Lq45. Jurnal Emba, 4(3), 717-728.

Noviantari, E., Wahyuni, M. A., \& Sinarwati, N. K. (2017). Pengaruh Tingkat Kesehatan Bank Dengan Metode Rgec ( Riks Profile , Good Corporate Governance , Earning , Capital ) Terhadap Return Saham ( Study Kasus Pada Bank Umum Swasta Nasional 
Devisa Yang Terdaftar Di Bursa Efek Indonesia Periode 2013-2015 ), 1.

Panjaitan, H. P., \& Wardani, D. P. K. (2014). Pengaruh Tingkat Kesehatan Bank Dengan Menggunakan Metode Rgec (Risk Profile, Gcg, Earning, Dan Capital) Terhadap Harga Saham (Studi Empiris Pada Bank Umum Yang Tercatat Di Bursa Efek Indonesia Tahun 2011-2014), 253-271.

Panjaitan, H. P., \& Wardani, D. P. K. (2016). Pengaruh Tingkat Kesehatan Bank Dengan Menggunakan Metode Rgec (Risk Profile, Gcg, Earning, Dan Capital) Terhadap Harga Saham (Studi Empiris Pada Bank Umum Yang Tercatat Di Bursa Efek Indonesia Tahun 2011-2014). Procuratio, 4(2), 253271.

Paramartha, D. G. D. A., \& Mustanda, I. K. (2017). Analisis Penilaian Tingkat Kesehatan Bank Pada Pt. Bank Central Asia .Tbk Berdasarkan Metode Rgec, 6(1), 3259.

Paramartha, I. M., \& Darmayanti, N. P. A. (2017). Penilaian Tingkat Kesehatan Bank Dengan Metode Rgec Pada Pt. Bank Mandiri (Persero), Tbk. E-Jurnal Manajemen Unud, 6(2), 948-974.

Parathon, A. A., Dzulkirom, \& Farah, D. (2012). Analisis Rasio Keuangan Perbankan Sebagai Alat Ukur Kinerja Keuangan Bank (Studi Kasus Pt. Bank Pembangunan Daerah Jawa Timur, Tbk Surabaya Periode 2009-2012), 1-11.

Peraturan Bank Indonesia. 2004. Peraturan Bank Indonesia No. 6/10/Pbi/2004 Tentang Sistem Penilaian Tingkat Kesehatan Bank Umum

Peraturan Bank Indonesia. 2011. Peraturan Bank Indonesia No. 13/1/Pbi/2011 Tentang Sistem Penilaian Tingkat Kesehatan Bank Umum

Peraturan Bank Indonesia. 2011. Peraturan Bank Indonesia Nomor: 13/24/Dpnp Tanggal 25 Oktober 2011 Perihal Sistem Penilaian Tingkat Kesehatan Bank Umum.

Permana, B. A. (2012). Analisis Tingkat Kesehatan Bank Berdasarkan Metode Camels Dan Metode Rgec. Jurnal Akuntansi Unesa, 1(1), 1-21.

Polii, P. J. ., Saerang, I., \& Mandagie, Y. (2014). Rasio Keuangan Pengaruhnya Terhadap Harga Saham Pada Bank Umum Swasta Nasional Devisa Yang Go Public Di Bursa Efek Indonesia. Jurnal Emba, 2(2), 9931004.

Praditasari, K. W. (2009). Analisis Pengaruh Tingkat Kesehatan Bank Terhadap Harga Saham Pada Perusahaan Perbankan Yang Go-Public Periode 2004-2008, (6).
Pramana, K. M., \& Artini, L. G. S. (2016). Analisis Tingkat Kesehatan Bank (Pendekatan Rgec) Pada Pt. Bank Danamon Indonesia Tbk, 5(6), 3849-3878.

Rahayu, R. I. (2014). Analisis Pengaruh Kinerja Keuangan Terhadap Perubahan Harga Saham Pada Perusahaan Perbankan Di Bursa Efek Indonesia Tahun, 54-69.

Ramadhani, F. (2009). Analisis Pengaruh Penerapan Corporate Governance Dan Growth Opportunity Pada Harga Saham Perusahaan Dalam Daftar Cgpi Yang Dirilis Iicg Periode 2005-2008. E-Journal Ekonomi Pada Universitas Gunadarma, 110.

Rosita, P., Muharam, H., \& Haryanto, M. (2014). Analisis Pengaruh Tingkat Kesehatan Bank Dengan Metode Camels Terhadap Return 2008-2014).

Sambul, S. H., Murni, S., \& Tumiwa, J. R. (2016). Pengaruh Kinerja Keuangan Perbankan Terhadap Harga Saham Yang Di Tawarkan Di Bursa Efek Indonesia (Studi Kasus 10 Bank Dengan Aset Terbesar). Jurnal Berkala Ilmiah Efisiensi, 16(2), 407-417.

Sari, Y. (2013). Pengaruh Profitabilitas, Kecukupan Modal Dan Likuiditas Terhadap Harga Saham (Perusahaan Perbankan Yang Terdaftar Di Bei), 1-26.

Siamat, D. (2005). Manajemen Lembaga Keuangan: Kebijakan Moneter Dan Perbankan (Kelima). Jakarta: Lembaga Penerbit Fakultas Ekonomi Universitas Indonesia.

Suardana, K. A. (2009). Pengaruh Rasio Camel Terhadap Return Saham.

Sugari, B. P., Sunarko, B., \& Giyatno, Y. (2015). Syariah Dan Konvensional Dengan Menggunakan Metode Rgec ( Risk Profile, Good Corporate Governance , Earnings , Dan Capital ), 5(1).

Surachim, A., Tanuatmodjo, H., \& Kussuma, P. (2016). Dampak Tingkat Profitabilitas Dan Nilai Pasar Pada Pergerakan Harga Saham Pt. Prasidha Aneka Niaga Tbk. Strategic, 11(19), 1-7.

Surachim, D. H. A., \& Izfs, R. D. (2016). Pengaruh Capital Structure Dan Working Capital Management Terhadap Profitabilitas. Journal of Business Management And Enterpreneurship Education, 1(1), 42-46.

Surat Edaran Bank Indonesia No. 13/24/Dpnp Tanggal 25 Oktober 2011 Perihal: Sistem Penilaian Tingkat Kesehatan Bank Umum.

Surat Edaran Bank Indonesia No.15/15/Dpnp Tanggal 29 April 2013 Perihal: Pelaksanaan 
Good Corporate Governance Bagi Bank Umum

Susilowati, E., \& Utiyati, S. (2016). Pengaruh Kinerja Keuangan Terhadap Harga Saham. Jurnal Ilmu Dan Riset Manajemen, 5(2), 115.

Takarini, N., \& Putra, U. H. (2013). Dampak Tingkat Kesehatan Bank Terhadap Perubahan Harga Saham Pada Perusahaan Perbankan Yang Go Public Di Bursa Efek Indonesia (Bei). Jurnal Neo-Bis, 7(Idx).

Tendelilin, E. (2010). Portofolio Dan Investasi Teori Dan Aplikasi. Yogyakarta: Kanisius.

Tumandung, C. O., Murni, S., \& N., B. D. (2017). Analisis Pengaruh Kinerja Keuangan Terhadap Harga Saham Pada Perusahaan Makanan Dan Minuman Yang Terdaftar Di Bei Periode 2011 - 2015. Jurnal Emba, 5(2), 1728-1737.

Ulfa, M., \& Budiyanto. (2014). Pengaruh Kinerja Keuangan Terhadap Harga Saham Bank Umum Milik Pemerintah Di Bei. Jurnal Ilmu \& Riset Manajemen, 3(11).

Vanhorne, J. C., \& Wachowicz, J. M. (2009). Fundamentals Of Financial Management (13th Ed.). Ft Prentice Hall.

Wahyuningtyas, R., \& Hartono, B. D. (2016). The Effect Of Bank Indonesia Certificates ,
Composite Stock Price Index And Exchange Rate On Mutual Fund Performance For Period Of 2012-2014. Asian Journal Of Management Sciences \& Education, 5(October), 13-19.

Wardani, D. K., \& Andarini, D. F. T. (2016). Pengaruh Kondisi Fundamental, Inflasi, Dan Suku Bunga Sertifikat Bank Indonesia Terhadap Harga Saham (Study Kasus Pada Perusahaan Real Estate Dan Property Yang Terdaftar Di Bursa Efek Indonesia Tahun 2010-2013). Jurnal Akuntansi, 4(2), 77-90.

Wijayaningsih, R., Rahayu, S. M., \& Saifi, M. (2015). Pengaruh Bi Rate , Fed Rate , Dan Kurs Rupiah Terhadap Indeks Harga Saham Gabungan ( Ihsg ) ( Studi Pada Bursa Efek Indonesia Periode 2008-2015 ). Jurnal Administrasi Bisnis (Jab), 33(2), 69-75.

Winarsih. (2014). Analisis Tingkat Kesehatan Bank Berdasarkan Risk-Based Bank Rating Dan Pengaruhnya Terhadap Harga Saham. Indonesia, Jurnal Akuntansi, 3(1), 71-80.

Zulhelmi, \& Utomo, R. B. (2013). Pengaruh Car, Bopo, Nim, Npl, Dan Ldr Terhadap Profitabilitas Perbankan Umum Milik Pemerintah Di. E-Jurnal Akuntansi Universitas Udayana, 5(2), 483-496. 